\title{
Formation of soft skills among students of higher educational institutions
}

\section{Formación de habilidades blandas en estudiantes de instituciones de educación superior}

\author{
Elena A. Pluzhnirova \\ margo2000@list.ru \\ Armavir State Pedagogical University, Krasnodar Territory, Armavir, Russia \\ https://orcid.org/0000-0001-5863-379X \\ Marina V. Zhivoglyad \\ mzhivoglyad@mail.ru \\ Armavir State Pedagogical University, Krasnodar Territory, Armavir, Russia \\ https://orcid.org/0000-0001-7683-7075 \\ Julia A. Kulagina \\ kulagina_yu.a@mail.ru \\ Penza State Technological University, Penza, Russia \\ https://orcid.org/0000-0002-8892-0367 \\ Irina M. Morozova \\ 89063981816@mail.ru \\ Penza State Technological University, Penza, Russia \\ https://orcid.org/0000-0003-2249-8332 \\ Natalia V. Titova \\ nvtitova77@mail.ru \\ Penza State University, Penza, Russia \\ https://orcid.org/0000-0001-5079-9568
}

Recibido: 19/12/2020

Aceptado: 16/01/2021

\begin{abstract}
The objective of the article was to analyze the experience of training and development of soft skills among students of higher education institutions. The methodology used in the study presents a comparative analysis of hard and soft skills, presents the results of student surveys on the advantages of hackathons in the training of soft skills. The conclusions determine that institutions of higher education for the formation of soft skills of students introduce innovative methods and means in the learning process. Hackathons and meetups act as real tools for soft skills training and competitive specialist training in general.
\end{abstract}


Key Words: soft skills, higher education institution, professional training, professional competencies, hackathon, professionalism.

\section{Resumen}

El objetivo del artículo fue realizar el análisis de la experiencia de formación y desarrollo de habilidades blandas entre estudiantes de instituciones de educación superior. La metodología utilizada en el estudio presenta un análisis comparativo de habilidades duras y blandas, presenta los resultados de encuestas a estudiantes sobre las ventajas de los hackatones en la formación de habilidades blandas. Las conclusiones determinan que las instituciones de educación superior para la formación de habilidades blandas de los estudiantes introducen métodos y medios innovadores en el proceso de aprendizaje. Los hackatones y los meetups actúan como herramientas reales para la formación de habilidades blandas y la formación de especialistas competitivos en general.

Hackatones. Se sugiere ir en cursiva porque en el español no existe

Palabras clave: habilidades blandas, institución de educación superior, formación profesional, competencias profesionales, hackathon, competitividad.

\section{Introduction}

The implementation of professional activities in the modern world is associated with the need for constant self-improvement of personnel, their adaptation to changing conditions to maintain competitiveness. Today, specialists with a flexible mind, criticality, systematic thinking, capable of creatively applying their skills, analyzing information, and solving problem problems in several ways are in demand.

The higher education system is faced with the task of forming students not only professional competencies (hard skills), but also the development of soft skills that allow them to quickly respond to changing professional conditions and quickly adapt to them: communication skills, teamwork skills, the ability to work with information (select the most relevant and systematize it), make decisions independently.

Therefore, higher education institutions offer students to participate in various projects (Yarygin et al., 2019b). One of the most relevant tools in professional training is the hackathon (Vaganova et al., 2020a). Conducting hackathons allows students to engage in active independent cognitive activity (Bakharev, 2019). By interacting, students develop various kinds of projects, the products of which can be in demand at the international level, ensuring its participants are in demand in the labor market. Students independently develop a project with the support of a teacher or project curator, adjust their activities to achieve a common result, learn to communicate, overcome conflicts and offer several options for solving problems that arise (Vaganova et al., 2020b). 
Various companies and industries are directly involved in the organization of hackathons, which, in the process of presenting projects by students, select the most active participants who in the future will be able to carry out professional activities in their organization (Braslavska \& Rozhi, 2020). Thus, the hackathon provides students with the opportunity to secure a job already at the stage of training (Yarygin et al., 2019a). Organizations, on the other hand, receive highly qualified creative professionals who can increase the company's competitiveness in the future by developing and implementing new ideas (Ponachugin et al., 2019).

In addition to hackathons, students take part in meetups. A meeting is an organized informal meeting of specialists in a specific field, where they can share and exchange experiences (Syrina et al., 2020). At meetups, students can get to know potential employers better and demonstrate their skills (Efremenko et al., 2020).

The ability to generate ideas, choose the most relevant of the proposed ideas, the ability to quickly navigate in new conditions, make forecasting, structuring and systematization are soft skills, without which it is impossible to carry out modern creative productive activities. Therefore, the formation of soft skills is becoming one of the most important tasks solved by higher educational institutions (Vaganova et al., 2019).

Project activities at hackathons, conferences and meetups allow solving the issue of the student's acquisition of both professional competencies and soft skills (general cultural and general professional) (Shashlo et al., 2018).

\section{Theoretical framework}

Rigid competencies are professional competencies that can be demonstrated, measured and assessed (Kiseleva et al., 2019). They are necessary for the implementation of specific professional activities. Soft skills imply a sequential study of situations in which the student is forced to make independent decisions. Soft (supraprofessional) competencies are universal knowledge that can be applied in all professions (Kidina, 2020). Having such skills allows the student to cope with the volatility, ambiguity and uncertainty of the world (Kharytonov et al., 2019). These are competencies related to the ability to cooperate, be creative, entrepreneurial, the ability to cope with stressful situations, be aware of the future and make appropriate predictions (Mazanyuk et al., 2020).

In the understanding of S.N. Batsunov, flexible skills are a collection of supraprofessional skills that contribute to the successful implementation of professional activities, ensuring high productivity and at the same time are not associated with a specific subject area (Batsunov et al., 2018).

In the formation of soft skills, the importance of entrepreneurial learning is distinguished (a concept that allows you to translate ideas into life, which includes personal development, the development of entrepreneurial skills) and experiential learning 114 Formation of soft skills among students of higher educational institutions. - Eduweb, 2021, enero-abril,
v.15, n.1./112-122 
(knowledge of the surrounding reality through understanding your own experience), when first a student gains practical experience, and then implements its comprehension (Aniskin et al., 2020).

Researchers usually identify two ways of developing flexible skills. Firstly, in the learning process by introducing individual courses, and secondly, using the potential of the studied disciplines in conjunction with extracurricular educational work.

However, hackathons and meetups expand the possibilities for the formation of soft skills. They form the ability to speak publicly and reasonably answer questions from the audience, form the ability to motivate another person, involve him in the team process, train the skills of self-organization and planning (Pichugina, Bondarchuk, 2019).

A wide range of soft skills was presented by the World Economic Forum at the Future of Jobs, which were divided into abilities, basic skills and cross-functional skills. The table shows a fragment of the list of soft skills identified by N.V. Lomovtseva (Lomovtseva, 2020).

Table 1. List of soft skills presented at the World Economic Forum

\begin{tabular}{|c|c|c|c|}
\hline Abilities & Basic skills & \multicolumn{2}{|c|}{ Cross functional skills } \\
\hline $\begin{array}{l}\text { 1. Cognitive abilities: } \\
\text { - flexibility; } \\
\text { - creativity; } \\
\text { - the logic of evidence; } \\
\text {-visualization; } \\
\text { - sensitivity to problem } \\
\text { situations }\end{array}$ & $\begin{array}{c}\text { 1. Content skills: } \\
\text { - active learning; } \\
\text { - implementation of } \\
\text { oral communication; } \\
\text { - implementation of } \\
\text { written } \\
\text { communication; } \\
\text { - information literacy }\end{array}$ & $\begin{array}{c}\text { 1. Social skills: } \\
\text { - implementation of } \\
\text { coordination; } \\
\text { - the presence of } \\
\text { emotional } \\
\text { intelligence; } \\
\text { - the skill of } \\
\text { negotiating; } \\
\text {-the skill of } \\
\text { persuasion; } \\
\text { - training others } \\
\end{array}$ & $\begin{array}{l}\text { 2. The skill of } \\
\text { resolving complex } \\
\text { non-standard } \\
\text { situations }\end{array}$ \\
\hline \multirow[t]{2}{*}{$\begin{array}{c}\text { 2. Physical abilities: } \\
\text { - good physical health; } \\
\text { - developed fine motor skills }\end{array}$} & $\begin{array}{l}\text { 2.Processing skills: } \\
\text { - hearing; } \\
\text { - developed critical } \\
\text { thinking; } \\
\text { - implementation of } \\
\text { reflection, } \\
\text { introspection and } \\
\text { analysis of the } \\
\text { activities of others }\end{array}$ & $\begin{array}{l}\text { 3. System skills: } \\
\text { - making appropriate } \\
\text { decisions; } \\
\text { - implementation of } \\
\text { system analysis; }\end{array}$ & $\begin{array}{l}\text { 4. Skills of } \\
\text { resource } \\
\text { management: } \\
\text { - financial; } \\
\text { - material; } \\
\text { - human; } \\
\text { - implementation of } \\
\text { time management }\end{array}$ \\
\hline & & $\begin{array}{l}\text { 5.Technical skills: } \\
\text { - use of technical } \\
\text { capabilities; } \\
\text { - operational literacy; } \\
\text { - identification of } \\
\text { technical problems }\end{array}$ & \\
\hline
\end{tabular}


Table 2. Key to difference game hard skills of soft skills

\begin{tabular}{llrl}
\hline Hard skills (professional competencies) & $\begin{array}{l}\text { Soft skills (general cultural and general } \\
\text { professional competencies) }\end{array}$ & (emotional \\
\hline The right hemisphere is involved (IQ, logic) & $\begin{array}{l}\text { Left hemisphere involved } \\
\text { intelligence) }\end{array}$ & . \\
\hline
\end{tabular}

Requirements remain the same regardless Requirements are fluid and situational of the organization and its corporate culture.

\begin{tabular}{ll}
\hline $\begin{array}{l}\text { Mastering is carried out in professional } \\
\text { educational institutions step by step }\end{array}$ & $\begin{array}{l}\text { There are no strictly defined stages. The } \\
\text { formation is carried out in the process of } \\
\text { acquiring certain experience }\end{array}$ \\
\hline There are certificates and diplomas & Have no certification \\
\hline
\end{tabular}

The formation of professional competencies and soft skills can be carried out in combination, however, if a certain step-by-step is characteristic of hard skills, then there is great variability in the development of soft skills (Shcerbakova et al., 2019).

The signs of the formation of soft skills include the following (Kipina, 2019).

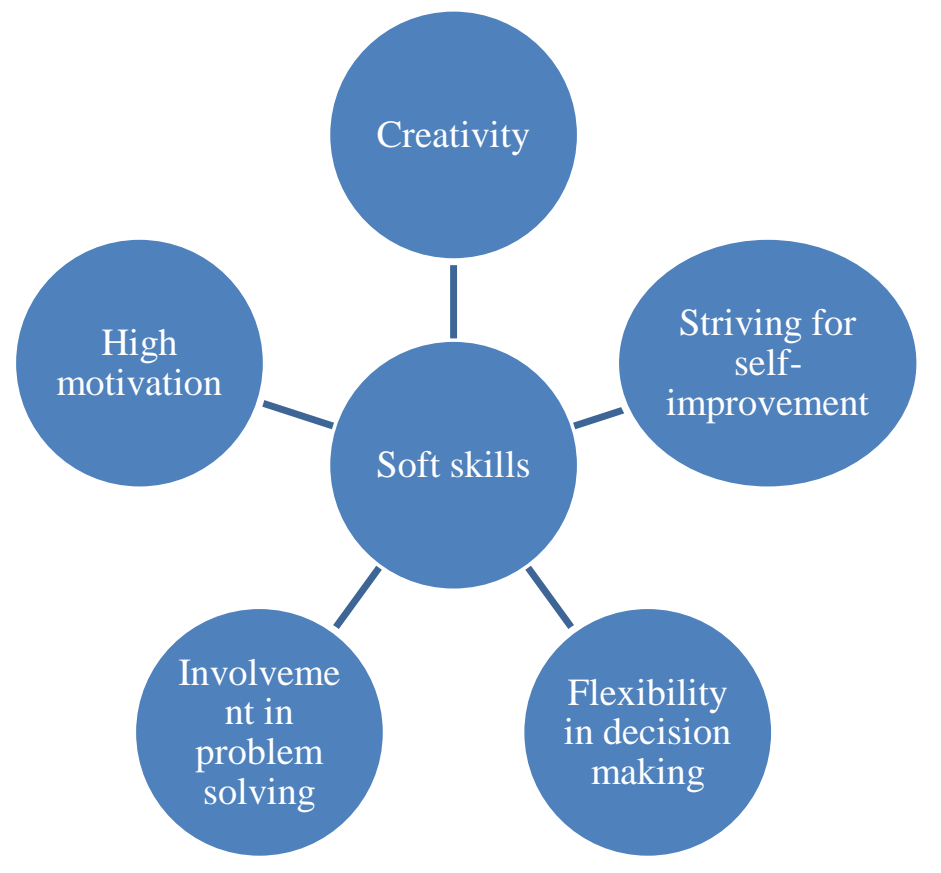

Fig. 1. Signs of the formation of soft skills in students.

Today, there are professions in which hard skills prevail over soft skills, but it should be noted that soft skills are skills of the future. And the more successful becomes the one who is ready to respond flexibly to emerging changes (Misakov et al., 2018). 


\section{Methodology}

The study aims to develop soft skills among university students. For this, the paper presents a comparative analysis of hard and soft skills. According to university professors, the most popular soft skills in the modern labor market were identified.

The online survey, conducted in 2020, was attended by teachers from various higher education institutions. The trainers were presented with a list of flexible skills consisting of 30 positions.

The respondents had to vote for soft skills, which, in their opinion, should be formed in higher education students in the first place (those skills that would ensure high demand in the labor market).

A survey was conducted among students of higher educational institutions and the most frequent answers were highlighted. The respondents were asked to answer a question about the benefits of hackathons.

\section{Results and discussion}

In the process of preparing students, trainings devoted to the development of certain soft skills were involved. For example, trainings dedicated to cognitive development allowed developing attention, speech, memory. Students were engaged in the processing of a large amount of professional information, studied terms, developed the ability to reflect, learned to apply self-control skills in stressful situations.

In classes devoted to the formation of research skills, students learned to work with sources of information, formulate research hypotheses, structure research work, and process results. All classes covered one or several groups of related skills, which make it possible to form effective behavioral models for several competencies. Developing agile skills involves learning by doing. That is, to enhance the activities of students, it is necessary to include them in professional activities already at the stage of training.

The international program Enactus is being implemented in the world, the participants of which are students of all courses and all forms of study. Through the program, students develop and implement entrepreneurial ideas, consistently mastering modern business technologies (Dalibozhko et al., 2018).

Teams have the opportunity to collaborate with organizations, administration, innovation scientists, and other students (Bulaeva et al., 2018).

Attracting students to international projects is one of the most effective tools in shaping soft skills and improving professional competencies (Nagovitsyn et al., 2020). The 
participating teams independently choose the number of projects and the timeframe for implementation. Projects can be both commercial and social.

In Russia, students are involved in various projects, including projects that the Innopolis University is engaged in. A large number of programs developed by the university are devoted to practical activities in the form of team projects. Students take part in cuttingedge research. A large number of students take part in the hackathons.

A survey was conducted among students from different universities and the most common answers were identified. The respondents were asked to answer a question about the benefits of hackathons.

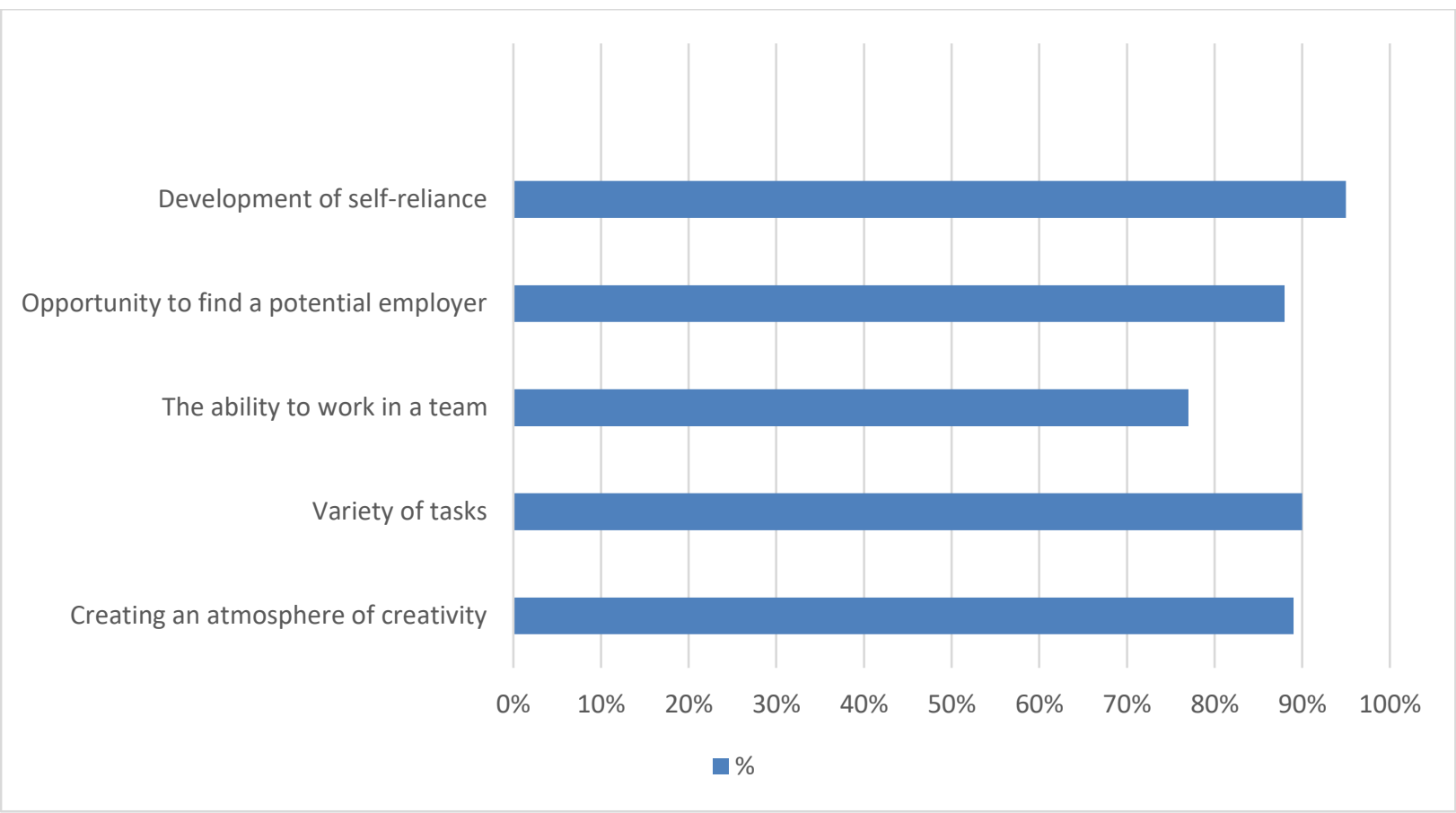

Fig. 2. Results of a survey of students about the benefits of hackathons.

Students' responses indicate their interest in participating in such events. They note that the hackathon provides an opportunity to independently build a strategy for achieving goals, but at the same time they can seek help from a curator who will direct their activities.

The advantages of hackathons in shaping soft skills are obvious. In the context of creativity, with the support of a teacher and a project curator, students can fully reveal their potential. 
The figure shows the most popular soft skills in the modern labor market, according to university professors. Teachers from various higher education institutions took part in the electronic survey.

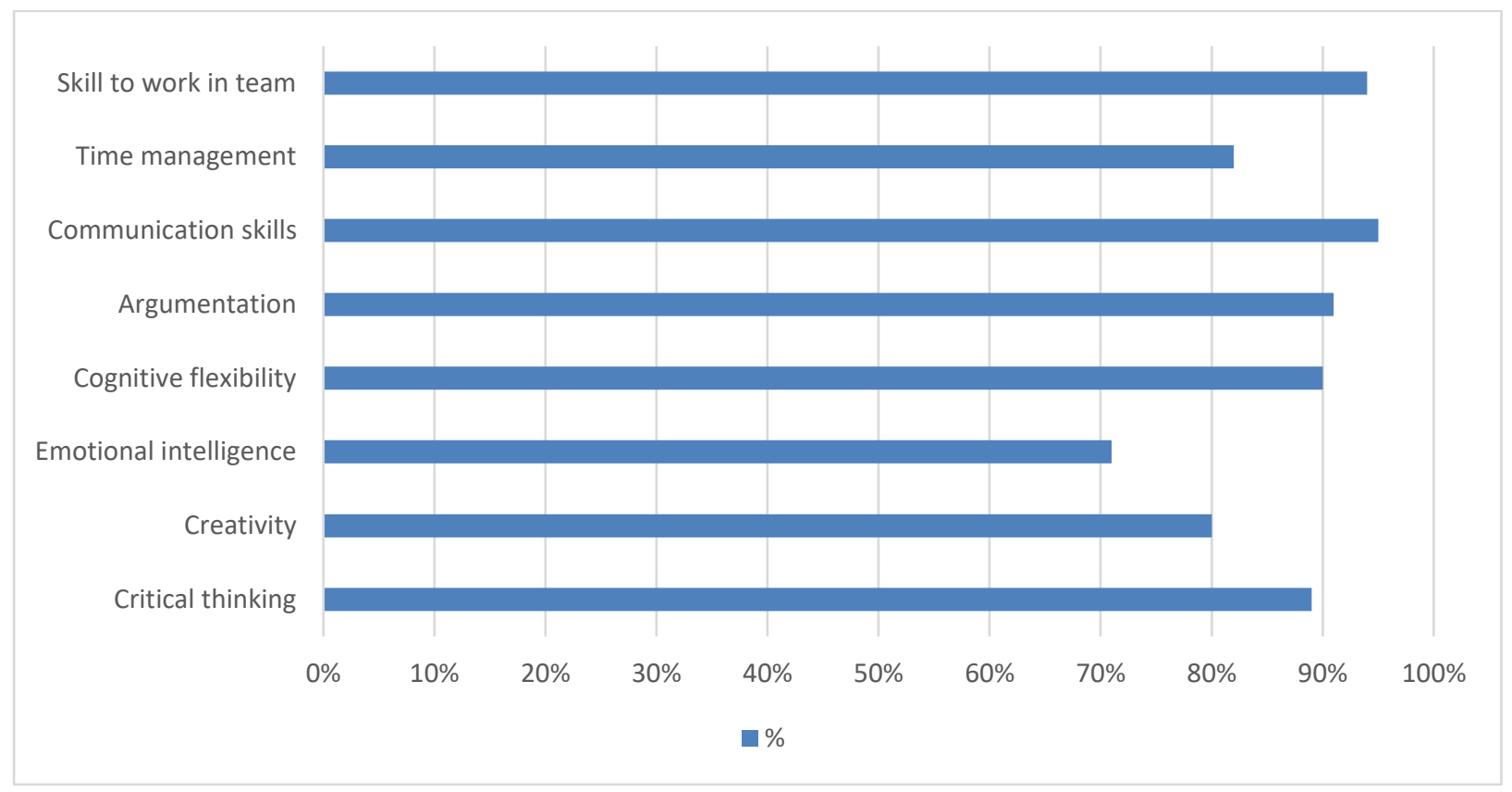

Fig. 3. Results of a survey to identify the soft skills most in demand in the labor market (according to university professors)

The results show that, first of all, a modern student (according to teachers) must master communication skills, the ability to interact in a team to achieve the best results, analyze information, and argue his position.

If the left hemisphere of the brain is involved in the formation of hard skills, IQ and logic developing, then the formation of soft skills involves the right hemisphere, therefore emotional intelligence is important in the development of soft skills, which makes it easy to interact with other members of the work team.

The demand for soft skills is growing. Therefore, higher education institutions are looking for new ways to form them among students.

\section{Conclusions}

The modern world is distinguished by high technological effectiveness and dynamic development of processes. Therefore, the most in demand are specialists who are capable of quick and flexible changes. The formation of soft skills ensures their competitiveness in the labor market. 
The formation of soft skills is carried out in various ways, but the most relevant tools are various conferences, hackathons and meetups, since they bring together specialists from different fields, provide an opportunity to exchange experiences and develop creative independence, the ability to communicate and overcome conflicts to achieve the best team results. The conducted research shows that students are aware of the advantages of hackathons and meetups in the formation of their competitiveness. In the process of participating in hackathons, students reveal their potential, become more independent, creative, ready to make responsible decisions.

\section{Referencias}

Aniskin, V. N., Korostelev, A. A., Lvovna, B. A., Kurochkin, A. V., \& Sobakina, T. G. (2020). Teaching potential of integrated learning technologies Smart, Stem and Steam. Revista De La Universidad Del Zulia, 11(29), 328-336.

Batsunov, S.N., Derech, I.I., Kungurova, I.M., Slizkov., E.V. (2018). Modern determinants of soft skills development. Scientific and methodological electronic magazine Concept. 4, Pp. 12-21.

Bulaeva, M. N., Vaganova, O. I., Koldina, M. I., Lapshova, A. V., Khizhnyi, A.V. (2018). Preparation of Bachelors of Professional Training Using MOODLE. Advances in intelligent systems and computing, 622, Pp. 406-411.

Bakharev, N. P. (2019). Creativity - a prerequisite for the formation of professional competences in specialists of technical direction of training. Scientific Vector of the Balkans, 3, 4 (6), 17-21.

Braslavska O. V., Rozhi I. G. (2020). Peculiarities of innovative learning in a modern educational environment. Balkan Scientific Review, 4, 2 (8), 24-26.

Dalibozhko, A., German M., Krakovetskaya I. (2018). Increasing competitiveness university graduates in the labor market: possibility of forming hard and soft skills in the international Enactus1 program. Izvestiya FEFU. Economics and Management. Pp.57-74.

Demidov, A., Tretyakov, A.L., Tretyakov, A.L. (2020). Development of Digital Skills and Media Education System: From the Organization of Environmental Education of Preschool Children to the ICT Competence of Teachers. Media Education (Mediaobrazovanie), 1, 11-23.

Efremenko L.V., Golovachev V.S., Grigoryeva A.S., Tretyakov A.L., Chertakova E.M. (2020). Environmental education technologies. Eduweb: Revista de Tecnología de Información y Comunicación en Educación. Vol. 14, 2, Pp. 109-122.

Kidina, I. M. (2020). Management of the pedagogical collective in the conditions of implementing distance learning. Baltic Humanitarian Journal. (Baltic Humanitarian Journal). Vol. 9 No 4 (33), Pp. 93-96.

Kharytonov, E., Kharytonova, O., Tolmachevska, Y., Fasii, B., \& Tkalych, M. (2019). Information Security and Means of Its Legal Support. Amazonia Investiga, 8(19), 255-265. https://amazoniainvestiga.info/index.php/amazonia/article/view/227

Kiseleva, O., Lebedev, A., Pinkovetskaia, I., Rojas-Bahamón, M., \& Arbeláez Campillo, D. (2019). Specialization and concentration of small and 
medium enterprises employees: Russian data. Amazonia Investiga, 8(20), 6-15. https://amazoniainvestiga.info/index.php/amazonia/article/view/59

Kipina O.A. (2019). Forming soft skills at bachelor degree students in a teachers training higher education institution. XXIX Ershov Readings. Ishim. Pedagogical education: challenges of the time. Collection of scientific articles. Pp. 41.

Lomovtseva N. V. (2020). Soft skills of students in the world of VUCA. Acmeology of vocational education. Materials of the 16th International Scientific and Practical Conference. Yekaterinburg, Pp. 95-99.

Mazanyuk, E.F., Tretyakov, A.L., \& Amichba, L.R. (2020). Game technologies as a tool of motivation and improvement the quality of university students' training. SHS Web of Conferences: International Scientific and Practical Conference «Teacher Professionalism: Psychological and Pedagogical Support of a Successful Career», Vol. 87...

Misakov, V., Khamzatov, V., Temrokova, A., Misakov, A., \& Dikareva, I. (2018). Strategic management of innovative agro-industrial projects. Amazonia Investiga, 7(14), 16-23. https://amazoniainvestiga.info/index.php/amazonia/article/view/442

Nagovitsyn, R. S., Vaganova, O. I., Kutepov, M. M., M. L. N., Kosenovich, O. V, Moeseev, Yu. V., Vorotova, M. S., \& Osipov, A. Y. (2020). Interactive Technologies in Developing Student's Motivation in Physical Education and Sport. International Journal of Applied Exercise Physiology, 9(6), 78-85.

Pichugina, G.A; Bondarchuk, A.I. (2019). "Structure of the training case in the organization of the educational process". In: humanitarian balkan research. Vol. 2, no. 4, pp. 5-7.

Ponachugin, A.V., \& Lapygin, Yu.N. (2019). "Digital Educational Resources of The University: Design, Analysis and Expertise". In: Vestnik Mininskogo universiteta (Vestnik of Minin University). Vol. 7 (2), 5. (in Russ).

Shashlo, N., Petruk, G., \& Korostelev, A. (2018). Determinants of integration interaction among the subjects of the entrepreneurial innovation ecosystem of macro region. Amazonia Investiga, 7(13), 351-363. https://amazoniainvestiga.info/index.php/amazonia/article/view/569

Shcerbakova, E.V., \& Shcerbakova T. N. (2019). Experience of Use of Remote Computer Technologies at The Organization of Independent Work of Students in The Conditions of a Mark and rating system. Baltic Humanitarian Journal. (Baltic Humanitarian Journal). Vol. 8, No 4 (29), Pp. 192-195.

Vaganova, O., Korostelev, A., Melnikov, D., Bulaeva, M., \& Chelnokova, E. (2020a). Students activities organization technology in environmental communities. Amazonia Investiga, 9(29), 37-44. https://amazoniainvestiga.info/index.php/amazonia/article/view/1364

Vaganova, O. I. Korostelev, A. A., Chelnokova, E.A., \& Bugoslavskaya, A.V. (2020b). Technology for compiling supporting abstracts in the organization of students' independent work. Revista Amazonia Investiga. 9. 376-382. https://amazoniainvestiga.info/index.php/amazonia/article/view/1254

Vaganova, O., Livshits, Y., Aleshugina, E., Smirnova, Z., \& Kutepova, L. (2019). Experience in developing electronic glossary in a higher education institution. 
Amazonia Investiga, 8(22), 247-253. Retrieved from https://amazoniainvestiga.info/index.php/amazonia/article/view/421

Yarygin O.N., Korostelev A.A., Akhmetov, L.G., \& Maseleno, A. (2019a). Modeling of competence as a tool of goal setting for education in modern society. International Journal of Recent Technology and Engineering, 7(6), Pp. 72-77.

Yarygin O.N., Korostelev A.A, Mukhutdinov R.H., \& Maseleno A. (2019b). Elections and russian citizens residing overseas: Prospects for internet voting. International Journal of Recent Technology and Engineering, 7(6), Pp. 52-57. 